\title{
Management of Chemotherapy-Induced Nausea and Vomiting (CINV): A Short Review on the Role of Netupitant-Palonosetron (NEPA)
}

This article was published in the following Dove Press journal: Core Evidence

Vito Lorusso'

Anna Russo (D)

Francesco Giotta (1D)

Paolo Codega $\mathbb{D}^{2}$

'Medical Oncology Unit, IRCCS Istituto Tumori "Giovanni Paolo II", Bari, Italy;

${ }^{2}$ Medical Affairs Department, Italfarmaco SpA, Cinisello Balsamo, Italy
Correspondence: Vito Lorusso Tel +390805555909

Email vitolorusso@me.com
Introduction: Antineoplastic drugs may induce several side effects, including chemotherapy-induced nausea and vomiting (CINV). Two neurotransmitters play a central role in mediating the emetic response: serotonin acting on the $5 \mathrm{HT} 3$ receptor and the substance P targeting the NK1 receptor. Indeed, a combination of a 5HT3 receptor antagonist (5HT3-RA) and a NK1 receptor antagonist (NK1-RA) together with dexamethasone has been shown to be very effective. In fact, this combination is actually widely used and recommended for CINV prophylaxis for highly emetogenic cisplatinbased adriamycin/cyclophosphamide (AC) and carboplatin-based regimens. NEPA (netupitant/palonosetron) is the only fixed combination antiemetic available and it is composed by the long-lasting second-generation 5HT3-RA palonosetron and the highly selective NK1-RA netupitant.

Aim: The aims of this short review were to analyze the role of NEPA in CINV prophylaxis and management taking in account the risk factors related to the patient and to the antineoplastic treatment.

Evidence Review: CINV development is not only correlated to the emetogenic potential of the antineoplastic drugs but is also very influenced by the patient characteristics and history, such as gender, age, alcohol intake, nausea during pregnancy and motion sickness. In pivotal and post-registration studies, NEPA has demonstrated to be effective and safe in both highly and moderately emetogenic chemotherapy.

Conclusion: A proper assessment of both chemotherapy- and patient-related risk factors is paramount to properly evaluate an appropriate prophylaxis of CINV and NEPA by simplifying the therapy, guarantees fully adherence to antiemetic guidelines, and consequently improves the control of CINV, especially in high risk patients.

Keywords: NEPA, netupitant, palonosetron, $\mathrm{NK}_{1}-\mathrm{RA}, 5 \mathrm{HT}_{3}-\mathrm{RA}, \mathrm{CINV}$, chemotherapy, vomiting, nausea

\section{Core evidence clinical impact summary for NEPA}

\begin{tabular}{|l|l|l|}
\hline Outcome Measure & Evidence & Implications \\
\hline Disease-oriented evidence & & \\
\hline $\begin{array}{l}\text { Efficacy on management of chemotherapy- } \\
\text { induced nausea }\end{array}$ & Clear & $\begin{array}{l}\text { Proved by RCT and observational } \\
\text { studies }\end{array}$ \\
\hline
\end{tabular}

(Continued) 
(Continued).

\begin{tabular}{|c|c|c|}
\hline $\begin{array}{l}\text { Efficacy on management of chemotherapy- } \\
\text { induced vomiting }\end{array}$ & Clear & $\begin{array}{l}\text { Proved by RCT and observational } \\
\text { studies }\end{array}$ \\
\hline Cardiac safety & Clear & Proved by RCT studies \\
\hline \multicolumn{3}{|l|}{ Patient-oriented evidence } \\
\hline Improvement in quality of life & Clear & $\begin{array}{l}\text { Proved by RCT and observational } \\
\text { studies }\end{array}$ \\
\hline High adherence to guidelines & Clear & $\begin{array}{l}\text { One shot administration provides } \\
\text { a complete adherence to guidelines for } \\
\text { most HEC and MEC regimens }\end{array}$ \\
\hline Sparing of corticosteroids & Moderate & $\begin{array}{l}\text { Observed in clinical practice. Trials are } \\
\text { currently underway }\end{array}$ \\
\hline \multicolumn{3}{|l|}{ Economic evidence } \\
\hline Cost effectiveness & Moderate & $\begin{array}{l}\text { A cost-effectiveness analysis suggests } \\
\text { that NEPA, providing a superior CINV } \\
\text { prevention, lowers total medical costs } \\
\text { due to CINV-related adverse events } \\
\text { compared to other antiemetic } \\
\text { regimens. }\end{array}$ \\
\hline
\end{tabular}

Abbreviations: RCT, randomized controlled trial; HEC, highly emetogenic chemotherapy; MEC, moderate emetogenic chemotherapy; CINV, chemotherapy-induced nausea and vomiting.

\section{Introduction}

Chemotherapy may induce several side effects, including nausea and vomiting (CINV). If not properly controlled, CINV can be very harmful to the patients, causing dehydration, undernourishment and electrolyte imbalance. These side effects can profoundly impact patients' quality of life and their adherence to the treatment. ${ }^{1,2}$

The incidence of CINV is conditioned by several risk factors that can be related either to the patient or to the treatment. $^{3}$

Different antineoplastic drugs induce different emetic patterns in terms of intensity, duration and peak. Drugs that induce vomiting in more than $90 \%$ of patients without any emetic prophylaxis are defined "highly emetogenic chemotherapy" (HEC), while those with a nausea and vomiting incidence between $30 \%$ and $90 \%$ are defined "moderately emetogenic chemotherapy" (MEC). CINV events can develop on the same day of the chemotherapy treatment (defined as "acute"), or on the days after the administration of the chemotherapy (defined as "delayed"). ${ }^{4}$ Different physiological mechanisms underlie the acute and the delayed CINV. In fact, the peripheral pathway, which takes place primarily in the gastrointestinal tract, is predominant in the development of the acute CINV and it is mediated by the action of serotonin on the $5 \mathrm{HT}_{3}$ receptors present on vagal afferents whereas the delayed CINV is predominantly mediated by the substance $\mathrm{P}$ that acts on the $\mathrm{NK}_{1}$ receptors. The latter is defined as "central pathway" since it takes place primarily within the central nervous system. ${ }^{5}$ The aim of this short review is to analyze the role of NEPA in CINV prophylaxis and management taking in account the risk factors related to the patient and to the antineoplastic treatment. No ethical approval was needed for this manuscript by EC (Ethical Committee) of our Institution because it is a review of the literature.

\section{HT $\mathrm{H}_{3}$-RAs and $\mathrm{NK}_{1}-\mathrm{RAs}$}

Several drugs are currently available for the prophylaxis and the control of the nausea and vomiting associated to antineoplastic treatments but the most effective belong to the class of the $5 \mathrm{HT}_{3}$ receptor antagonists $\left(5 \mathrm{HT}_{3}\right.$-RAs) or to the $\mathrm{NK}_{1}$ receptor antagonists $\left(\mathrm{NK}_{1}-\mathrm{RAs}\right)$. These drugs are also available in different formulation (oral, 
intravenous or transdermal patch). A combination of a $5 \mathrm{HT}_{3}-\mathrm{RA}$ and a $\mathrm{NK}_{1}$ - $\mathrm{RA}$ together with dexamethasone is actually the most recommended for CINV prophylaxis, in particular for highly emetogenic treatments. ${ }^{6-8}$

The aim of this short review is to analyze the role of NEPA (netupitant/palonosetron) in CINV prophylaxis and management, taking in account the risk factors related to the patients and to the emetogenic potential of the antineoplastic treatment.

\section{$5 \mathrm{HT}_{3}$-RAs}

The class of the $5 \mathrm{HT}_{3}$-RAs can be sub-classified in two main groups characterized by different pharmacological, pharmaco-dynamic and clinical features: the first generation $5 \mathrm{HT}_{3}-\mathrm{RA}$ group, as ondansetron, dolasetron, granisetron and tropisetron and the second-generation $5 \mathrm{HT}_{3}-\mathrm{RA}$ constituted by palonosetron. ${ }^{5}$

First-generation $5 \mathrm{HT}_{3}$-RAs are characterized by a short half-life (from 5 to 11 hours). These molecules bind to the $5 \mathrm{HT}_{3}$ receptor, establishing a competition for the receptor occupancy. This mechanism is effective but transient and do not cause internalization of the receptor. ${ }^{9}$

On the contrary, palonosetron has a half-life of 40 hours, much longer compared to first-generation compounds. Moreover, its mechanism of action is also different, since it acts by an allosteric binding to the $5 \mathrm{HT}_{3}$ receptor. This causes a positive cooperation on the other site leading to a higher and longer affinity with the receptor and to its internalization. Moreover, palonosetron exerts an inhibitory action on the $\mathrm{NK}_{1}$ pathway (cross-talk pathway) therefore potentiating its clinical activity (Figure 1). ${ }^{9}$

These differences translate into a statistically significant clinical superiority of palonosetron, compared to the first generation compounds as demonstrated in a number of clinical studies. ${ }^{10-12}$ Moreover, a single administration of palonosetron on the day of chemotherapy is usually sufficient to protect the patient from CINV for the entire cycle, the others 5HT3-RA may need of multiple doses for a proper CINV management. ${ }^{13}$

\section{$\mathrm{NK}_{\text {I }}$-RAs}

The association of a $\mathrm{NK}_{1}-\mathrm{RA}$ with a $5 \mathrm{HT}_{3}$-RA has quite enhanced the efficacy of CINV prophylaxis, especially in the control of the delayed phase, where the Substance P plays its major role. ${ }^{5}$ The drugs belonging to this family are aprepitant, netupitant and rolapitant. They share the same mechanism of action but they profoundly differ on

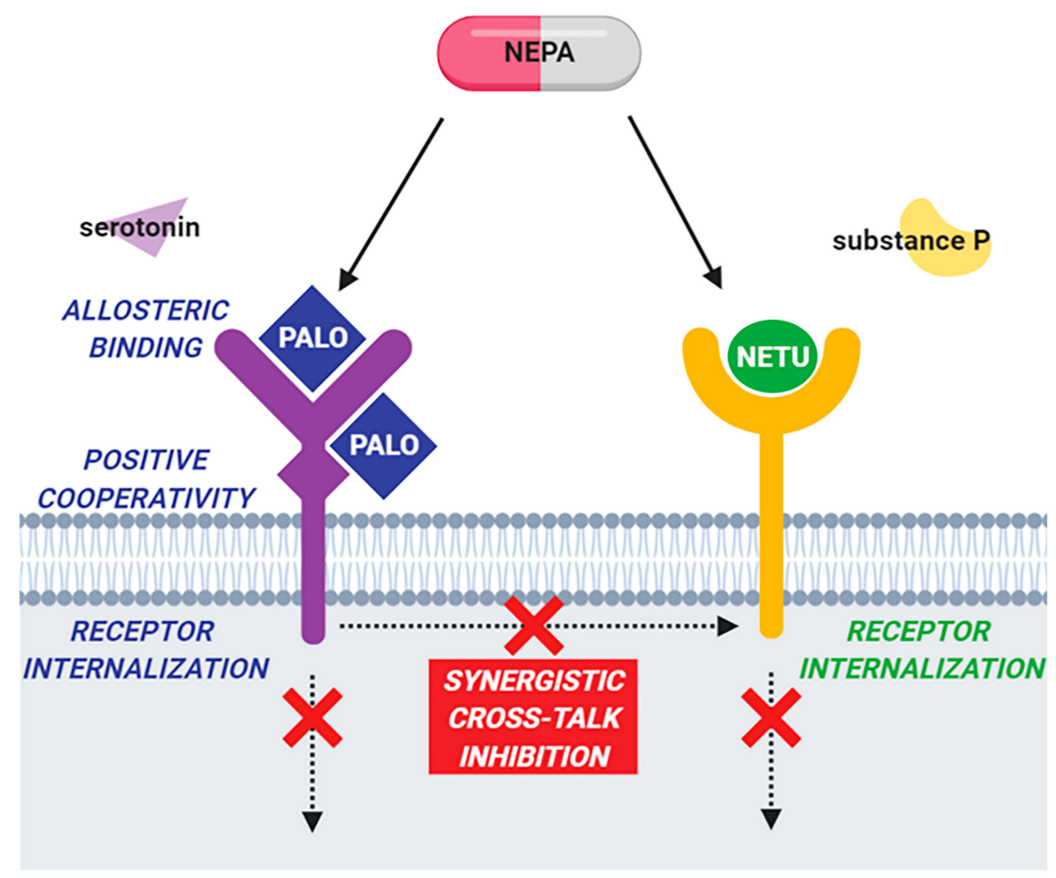

Figure I Cartoon showing the mechanism of action of NEPA. Palonosetron (PALO) acts on the $5 \mathrm{HT}_{3}$ receptor via allosteric binding, generating a positive cooperativity that strongly blocks $5 \mathrm{HT}_{3}$ signaling. This blockage also causes receptor internalization. Netupitant (NETU) binds the NK, receptor and inhibits its signaling. Moreover, concomitant administration of PALO and NETU results in a cross-talk inhibition between the two pathways that has a synergistic inhibitory effect. NEPA, netupitantpalonosetron; $5 \mathrm{HT} 3$ receptor, serotonin type 3 receptor; NKI receptor, neurokinin type I receptor. 
their half-life. Indeed, aprepitant has a half-life of about 9-13 hours, netupitant of 96 hours, while rolapitant of 169-183 hours. ${ }^{14,15}$ This pharmacokinetic feature of the different $\mathrm{NK}_{1}$-RA impacts on the dosage of these molecules for the proper management of CINV. In fact, aprepitant requires three oral administrations, given the first on the day of the chemotherapy and the other two, at lower dosage on the subsequent days at home. ${ }^{16}$ Fosaprepitant, which is an aprepitant pro-drug for intravenous administration, is given only on day 1 when the patient receives chemotherapy, but it requires the administration of oral dexamethasone on days $2-4 .^{16}$

Rolapitant is a highly selective NK1-RA characterized by having a half-life of more than a week. ${ }^{15}$ Due to this characteristic, it is supplied in a single administration of two capsules on the day of chemotherapy and it does not require any other supplementation at home. ${ }^{17}$ Rolapitant also differs from aprepitant and netupitant since it does not induce nor inhibit the cytochrome 3A4 (CYP3A4) and therefore dexamethasone adjustment is not required. ${ }^{15}$ On the other hand, it may interact with drugs that are metabolized by the CYP2D6. ${ }^{18}$

\section{NEPA}

NEPA is the first fixed antiemetic combination composed by the long lasting second-generation $5 \mathrm{HT}_{3}$-RA palonosetron and the highly selective $\mathrm{NK}_{1}$-RA netupitant available as oral formulation. Moreover, FDA recently approved a combination of fosnetupitant plus palonosetron for intravenous use. A single dose of NEPA acts on the principal pathways involved in the mechanisms controlling nausea and vomiting in a synergistic way with an appropriate half-life to cover both the acute and delayed phase (Figure 1). ${ }^{14}$ Their synergic effect on the inhibition of $\mathrm{NK}_{1}$ by pathway cross-talk and their role in receptor internalization have been largely demonstrated. ${ }^{19,20}$ Moreover, the co-administration of netupitant and palonosetron shows no changes in pharmacokinetic parameters as compared with single administration. ${ }^{21}$

\section{CINV Risk Factors}

Etiology of CINV is complex and not fully understood. Several risk factors concur in the development of CINV that can be categorized in two main groups: chemotherapyrelated and patient-related risk factors. ${ }^{3}$ The proper assessment of the emetogenic potential of the drugs combined with the individual risk factors, which can be collected before the start of the treatment, is essential to evaluate an appropriate CINV prophylaxis. $^{22}$ An algorithm that take into account both treatment- and patient-related risk factors is also available and can be consulted online (www.riskcinv.org). ${ }^{23}$

\section{Chemotherapy-Related Risk Factors}

The type of antineoplastic drugs, administered in the chemotherapy regimen, is the first risk factor that has to be evaluated. Regimens that include highly emetogenic drug are at higher risk of inducing CINV compared to regimens containing less emetogenic compounds. However, most chemotherapy protocols consist of combinations of different drugs generating various emetogenic stimuli that may differ in terms of intensity but also in terms of duration and peak. Therefore, despite current international guidelines categorize the recommended CINV prophylaxis only according to the highest emetogenic drug of chemotherapy schedule, it is clear that the proper evaluation of CINV is more complex. Moreover, different $\mathrm{NK}_{1}$-RAs have different posology (ie, aprepitant should be administered in three days) and this could affect the adherence to the prophylactic treatment. $^{24,25}$ All these factors should be taken in account, especially if the patient undergoing the treatment presents also other risk factors. ${ }^{3}$

\section{Patient-Related Risk Factors}

Several clinical studies have established that the development of CINV is highly correlated with patient features and history, such as gender, age, alcohol intake, limited sleep, number of previous chemotherapy cycles, nausea during pregnancy and motion sickness. ${ }^{3,23}$ Moreover, few studies proposed also other risk factors, in particular anxiety, expectation and concomitant consumption of opioid drugs or serotonin specific reuptake inhibitors. ${ }^{3}$

Female sex is a well-established risk factor for developing CINV by a mechanism that is not fully understood. Additionally, these patients may have also developed nausea and/or vomiting during pregnancy, therefore increasing the risk of CINV. This is particularly relevant in breast and gynecological cancer. Indeed, by definition these tumors can only rise in female patient and often also affect young patient, adding another risk factor. Therefore, in these patients CINV management should be carefully evaluated, considering also these patient-related risk factors. ${ }^{23}$ It has been demonstrated that NEPA is a very effective drug for CINV prophylaxis in these settings. In female patients with breast cancer receiving anthracycline/cyclophosphamide (AC)-based chemotherapy it was statistically superior in complete response (no vomiting and no use of rescue medication) during the acute, delayed, and overall phases, as 
compared to palonosetron. ${ }^{26}$ Similarly, NEPA was also effective in CINV management in female patients undergoing treatment for gynecological cancer. ${ }^{27}$ Moreover, in patients with breast cancer, the role of NEPA is important also for its cardiac safety profile, since those patients are at high risk to develop cardiomyopathy related to breast cancer treatment. ${ }^{28}$ A randomized, placebo-controlled study performed on 197 healthy subjects established the cardiac safety on NEPA, with no significant effects on QTc prolongation, heart rate, PR interval, QRS and cardiac morphology. ${ }^{29}$

All patients that had previous episodes of nausea and vomiting are also particularly at risk of CINV. This includes nausea and/or vomiting during pregnancy, motion sickness and to previous chemotherapy treatment. ${ }^{3,23}$ In fact, uncontrolled CINV in previous cycles increases more than five-fold the probability to develop CINV in subsequent cycles. ${ }^{23}$ Therefore, it is very important to offer the best available prophylactic treatment starting from the first chemotherapy cycle, as recommended by international guidelines, especially in patient with more risk factors.

The patient age and alcohol intake are also predictive factors for developing CINV. With this regard, it has been demonstrated that being a young patient (less than 60 years) is correlated to an increase of more than $40 \%$ probability to nausea and vomiting during chemotherapy. ${ }^{23}$ Low alcohol consumption (less than $44 \mathrm{~mL}$ /day) is also correlated with an increased CINV susceptibility. ${ }^{3}$

\section{CINV Management Guidelines}

There are different sets of guideline recommendations for antiemetic treatments: the most internationally recognized are those from the Multinational Association of Supportive Care in Cancer/European Society for Medical Oncology (MASCC/ESMO), the American Society of Clinical Oncology (ASCO) and the National Comprehensive Cancer Network (NCCN). ${ }^{6-8}$ All these guidelines are evidence-

Table I Comparison of Different CINV Prophylactic Treatments in Randomized Pivotal Studies in Cisplatin-Based Regimes

\begin{tabular}{|c|c|c|c|c|}
\hline Study and Study Arms & $\begin{array}{l}\text { Number of } \\
\text { Randomized } \\
\text { Patients per Arm }\end{array}$ & Cancer Type & Complete Response & No Significant Nausea \\
\hline $\begin{array}{l}\text { Poli Bigelli et al Cancer. } 2003^{39} \\
\text { APR+OND+DEX } \\
\text { OND+DEX }\end{array}$ & $\begin{array}{l}260 \\
263\end{array}$ & $\begin{array}{l}\text { Lung } 36 \% \text {; Urogenital } \\
39 \% \text {; Head and neck } 8 \% \text {; } \\
\text { other a\% }\end{array}$ & $\begin{array}{l}\text { Acute: } 82.8 \% \text { vs } 68.4 \% * \\
\text { Delayed: } 67.7 \% \text { vs } 46.8 \% * \\
\text { Overall: } 62.7 \% \text { vs } 43.3 \% *\end{array}$ & $\begin{array}{l}\text { Acute: not performed } \\
\text { Delayed: } 73 \% \text { vs } 65 \% \\
\text { Overall: } 71 \% \text { vs } 64 \%\end{array}$ \\
\hline $\begin{array}{l}\text { Hesketh et al J Clin Oncol. } \\
2003^{40} \\
\text { APR+OND+DEX } \\
\text { OND+DEX }\end{array}$ & $\begin{array}{l}260 \\
261\end{array}$ & $\begin{array}{l}\text { Lung } 42 \% \text {; Urogenital } \\
23 \% \text {; other } 35 \%\end{array}$ & $\begin{array}{l}\text { Acute: } 89.2 \% \text { vs } 78.1 \% * \\
\text { Delayed: } 75.4 \% \text { vs } 55.8 \% * \\
\text { Overall: } 72.7 \% \text { vs } 52.3 \% *\end{array}$ & $\begin{array}{l}\text { Acute: } 90.6 \% \text { vs } 86.5 \% \\
\text { Delayed: } 75.3 \% \text { vs } 68.5 \% \\
\text { Overall: } 73.2 \% \text { vs } 66.0 \%\end{array}$ \\
\hline $\begin{array}{l}\text { Grunberg et al J Clin Oncol. } \\
20 \mathrm{II}^{41} \\
\text { FOS+OND+DEX } \\
\text { APR+OND+DEX }\end{array}$ & $\begin{array}{l}1147 \\
1175\end{array}$ & $\begin{array}{l}\text { Lung } 47 \% \text {; GI } 21 \% \text {; } \\
\text { Urogenital } 15 \% \text {; other } \\
\text { I7\% }\end{array}$ & $\begin{array}{l}\text { Acute: } 89.0 \% \text { vs } 88.0 \% \\
\text { Delayed: } 74.3 \% \text { vs } 74.2 \% \\
\text { Overall: } 71.9 \% \text { vs } 72.3 \%\end{array}$ & $\begin{array}{l}\text { Acute: not performed } \\
\text { Delayed: not performed } \\
\text { Overall: } 70.1 \% \text { vs } 70.4 \%\end{array}$ \\
\hline $\begin{array}{l}\text { Hesketh et al Ann Oncol. } 2014^{33} \\
\text { NEPA+DEX } \\
\text { PAL+DEX }\end{array}$ & $\begin{array}{l}135 \\
136\end{array}$ & $\begin{array}{l}\text { Urogenital } 29 \% \text {; Lung } \\
28 \% \text {; Head and neck } 21 \% \text {; } \\
\text { GI I2\%; other } 10 \%\end{array}$ & $\begin{array}{l}\text { Acute: } 98.5 \% \text { vs } 89.7 \% * \\
\text { Delayed: } 90.4 \% \text { vs } 80.1 \% * \\
\text { Overall: } 89.6 \% \text { vs } 76.5 \% *\end{array}$ & $\begin{array}{l}\text { Acute: } 98.5 \% \text { vs } 93.4 \% * \\
\text { Delayed: } 90.4 \% \text { vs } 80.9 \% * \\
\text { Overall: } 89.6 \% \text { vs } 79.4 \% *\end{array}$ \\
\hline $\begin{array}{l}\text { Rapoport et al Lancet Oncol. } \\
2015(\text { HEC-I) } \\
\text { ROL+GRA+DEX } \\
\text { GRA+DEX }\end{array}$ & $\begin{array}{l}264 \\
262\end{array}$ & $\begin{array}{l}\text { Lung } 38 \% \text {; Head and neck } \\
21 \% \text {; Urogenital } 9 \% \text {; other } \\
32 \%\end{array}$ & $\begin{array}{l}\text { Acute: } 84 \% \text { vs } 74 \% * \\
\text { Delayed: } 73 \% \text { vs } 58 \% * \\
\text { Overall: } 70 \% \text { vs } 56 \% *\end{array}$ & $\begin{array}{l}\text { Acute: } 86 \% \text { vs } 79 \% * \\
\text { Delayed: } 73 \% \text { vs } 65 \% * \\
\text { Overall: } 72 \% \text { vs } 63 \% *\end{array}$ \\
\hline $\begin{array}{l}\text { Rapoport et al Lancet Oncol. } \\
2015 \text { (HEC-2) } \\
\text { ROL+GRA+DEX } \\
\text { GRA+DEX }\end{array}$ & $\begin{array}{l}271 \\
273\end{array}$ & $\begin{array}{l}\text { Lung } 49 \% \text {; Head and neck } \\
16 \% \text {; GI } 9 \% \text {; other } 26 \%\end{array}$ & $\begin{array}{l}\text { Acute: } 83 \% \text { vs } 79 \% \\
\text { Delayed: } 70 \% \text { vs } 62 \% * \\
\text { Overall: } 68 \% \text { vs } 60 \%\end{array}$ & $\begin{array}{l}\text { Acute: } 90 \% \text { vs } 86 \% \\
\text { Delayed: } 75 \% \text { vs } 69 \% \\
\text { Overall: } 73 \% \text { vs } 68 \%\end{array}$ \\
\hline
\end{tabular}

Note: *Results are statistically significant.

Abbreviations: CINV, chemotherapy-induced nausea and vomiting; APR, aprepitant; FOS, fosaprepitant; ROL, rolapitant; OND, ondansetron; GRA, granisetron; PALO, palonosetron; NEPA, netupitant-palonosetron; DEX, dexamethasone; GI, gastrointestinal. 
Table 2 Comparison of Different CINV Prophylactic Treatments in Randomized Pivotal Studies in AC-Based Regimes

\begin{tabular}{|c|c|c|c|}
\hline Study and Study Arms & $\begin{array}{l}\text { Number of } \\
\text { Randomized } \\
\text { Patients per } \\
\text { Arm }\end{array}$ & Complete Response & No Significant Nausea \\
\hline $\begin{array}{l}\text { Warr et al Clin Oncol. } 2005^{42} \\
\text { APR+OND+DEX } \\
\text { OND+DEX }\end{array}$ & $\begin{array}{l}438 \\
428\end{array}$ & $\begin{array}{l}\text { Acute: } 76 \% \text { vs } 69 \% * \\
\text { Delayed: } 55 \% \text { vs } 49 \% \\
\text { Overall: } 51 \% \text { vs } 42 \% *\end{array}$ & $\begin{array}{l}\text { Acute: not performed } \\
\text { Delayed: not performed } \\
\text { Overall: } 61 \% \text { vs } 56 \%\end{array}$ \\
\hline $\begin{array}{l}\text { Aapro et al Ann Oncol. } 2014^{26} \\
\text { NEPA+DEX } \\
\text { PAL+DEX }\end{array}$ & $\begin{array}{l}724 \\
725\end{array}$ & $\begin{array}{l}\text { Acute: } 88.4 \% \text { vs } 85.0 \% * \\
\text { Delayed: } 76.9 \% \text { vs } 69.5 \% * \\
\text { Overall: } 74.3 \% \text { vs } 66.6 \% *\end{array}$ & $\begin{array}{l}\text { Acute: } 87.3 \% \text { vs } 87.9 \% \\
\text { Delayed: } 76.9 \% \text { vs } 71.3 \% * \\
\text { Overall: } 74.6 \% \text { vs } 69.1 \% *\end{array}$ \\
\hline $\begin{array}{l}\text { Schwartzberg et al Lancet Oncol. } 2015^{43} \\
\text { ROL+GRA+DEX } \\
\text { GRA+DEX }\end{array}$ & $\begin{array}{l}344 \\
359\end{array}$ & $\begin{array}{l}\text { Acute: } 77 \% \text { vs } 77 \% \\
\text { Delayed: } 67 \% \text { vs } 60 \% * \\
\text { Overall: } 63 \% \text { vs } 55 \% *\end{array}$ & $\begin{array}{l}\text { Acute: not performed } \\
\text { Delayed: not performed } \\
\text { Overall: not performed }\end{array}$ \\
\hline
\end{tabular}

Note: *Results are statistically significant.

Abbreviations: CINV, chemotherapy-induced nausea and vomiting; AC, anthracycline-cyclophosphamide; APR, aprepitant; ROL, rolapitant; OND, ondansetron; GRA, granisetron; PAL, palonosetron; NEPA, netupitant + palonosetron; DEX, dexamethasone.

based and largely overlap on the recommended treatments, but all indicate that the main objective is to prevent rather than treat nausea and vomiting induced by chemotherapy. The antiemetic guidelines recommend the use of a triple combination of $\mathrm{NK}_{1}-\mathrm{RA}$, a $5 \mathrm{HT}_{3}-\mathrm{RA}$ and dexamethasone for HEC and AC-based chemotherapy in the first day of the treatment, based on the results of several pivotal studies conducted in these settings (Tables 1 and 2). In addition, for these regimens, recently ASCO invites to consider also olanzapine as a fourth drug, if nausea is a concern. ${ }^{6}$ In case the $\mathrm{NK}_{1}$-RA used in the first day is aprepitant, it should also be administered in the following days to prevent delayed CINV. $^{6-8}$

Regarding MEC settings, guidelines do not require the administration of a $\mathrm{NK}_{1}-\mathrm{RA}$, unless in case of carboplatinbased regimens. Indeed, specific metanalysis have demonstrated that a triple combination prophylaxis is effective in patients undergoing chemotherapy treatments containing carboplatin (Figure 2). ${ }^{27,30}$ Therefore, guidelines have been modified accordingly. ${ }^{6-8}$

Several studies were conducted to evaluate the adherence to antiemetic guidelines and, although there is variability
A

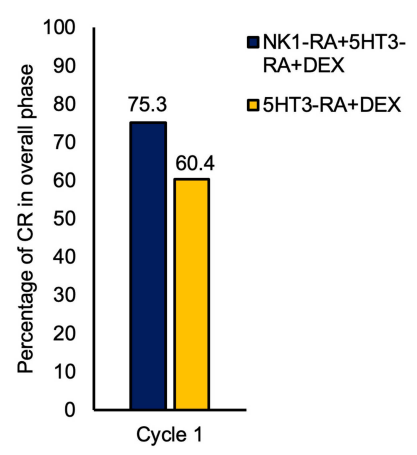

B

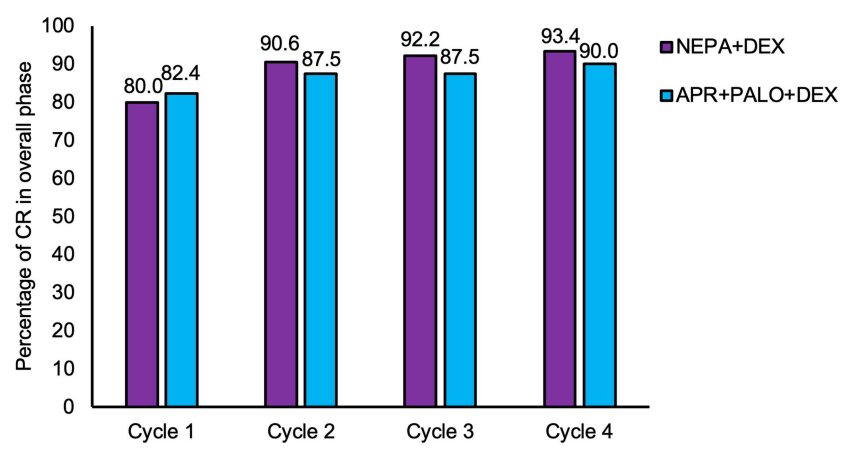

Figure 2 Post hoc analysis on carboplatin-based regimes. (A) Histograms showing the effect of a CINV prophylaxis with or without NK 1 -RA on the first chemotherapy cycle. Adapted from Critical Reviews in Oncology/Hematology, Vol I24, Di Maio M, Baratelli C, Bironzo P, et al, Efficacy of neurokinin-I Receptor Antagonists in the Prevention of Chemotherapy-Induced Nausea and Vomiting in Patients Receiving Carboplatin-Based Chemotherapy: A Systematic Review and Meta-Analysis, Pages No. 2I-28, Copyright (2018), with permission from Elsevier. ${ }^{44}$ (B) Histograms showing the CR rate on patients treated with NEPA+DEX compared with patients treated with APR+PALO+DEX. Adapted by permission from Springer Nature Customer Service Centre GmbH: Springer Nature, Supportive Care in Cancer. Efficacy Benefit of an NKI Receptor Antagonist (NKIRA) in Patients Receiving Carboplatin: Supportive Evidence With NEPA (A Fixed Combination of the NKI RA, Netupitant, and Palonosetron) and Aprepitant Regimens, Jordan K, Gralla R, Rizzi G, et al, [COPYRIGHT] (2016). ${ }^{45}$

Abbreviations: CINV, chemotherapy-induced nausea and vomiting; CR, complete response; NEPA, netupitant-palonosetron; 5HT3-RA, serotonin type 3 receptor antagonist; NKI-RA, neurokinin type I receptor antagonist; DEX, dexamethasone; APR, aprepitant; PALO, palonosetron. 
depending on the country, even more recent reports reveal a general low adherence. ${ }^{24,25,31}$ In fact, an Italian study on patients with breast cancer undergoing AC-chemotherapy reported that only $43.5 \%$ of the patients were treated with a CINV prophylaxis for the overall phase according to the national guidelines. ${ }^{31}$ Similarly, a survey collected among American oncology nurses revealed low adherence to guidelines, especially during the delayed phase following HEC, where only $25 \%$ of nurses reported administration of guidelines-recommended drugs. ${ }^{25}$ Moreover, these studies reported that a high adherence to guidelines increases the odds to be protected from CINV. ${ }^{24,31}$

NEPA, being a fixed combination of a $5 \mathrm{HT}_{3}-\mathrm{RA}$ and a $\mathrm{NK}_{1}-\mathrm{RA}$, gives the clinicians a simplified therapeutic option ensuring optimal adherence to therapy, which is a key requirement to obtain the maximum efficacy in the prophylaxis of $\mathrm{CINV}^{32}$ Moreover, NEPA is administered only once just before the chemotherapy treatment under medical supervision, guaranteeing 100\% adherence to guidelines.

\section{Recent Developments of NEPA Clinical Profile}

Efficacy of NEPA in preventing CINV induced by either HEC and MEC have been evaluated using palonosetron as reference in formal pivotal studies, which lead to the registration of the drug. ${ }^{26,33}$ More recently, other studies were conducted to further investigate NEPA efficacy and expand its clinical profile in different settings or populations.

A Phase III clinical trial was conducted in Asia on 829 patients receiving HEC using aprepitant and granisetron as reference arm, which was the first head-to-head study designed to compare the efficacy of two $\mathrm{NK}_{1}-\mathrm{RA} / 5 \mathrm{HT}_{3}$ RA regimens. ${ }^{34}$ The primary endpoint of non-inferiority between the two regimens was achieved: overall $\mathrm{CR}$ rate was $73.8 \%$ for single dose NEPA plus dexamethasone and $72.4 \%$ for 3-day oral aprepitant plus granisetron and dexamethasone. Importantly, the secondary endpoints, such as no emesis and no significant nausea rates were numerically in favor of NEPA in the delayed as well as in the overall phases. $^{34}$

Usually, CINV studies focus the investigation of antiemetic properties on the first cycle of chemotherapy, but efficacy of NEPA was also evaluated and confirmed over multiple cycles in different chemotherapy settings. With this regard, a post-hoc analysis of two studies showed that NEPA was highly effective in preventing both acute and delayed CINV over multiple chemotherapy cycles of HEC, $\mathrm{AC}$, and MEC regimens. ${ }^{35}$ These results were confirmed in a very recent study designed to investigate the efficacy of NEPA in breast cancer patients receiving adjuvant $\mathrm{AC}$ chemotherapy over multiple cycles and during the intercycle period. ${ }^{36}$ In 149 patients on study, the proportion of patients with an overall CR was $70.5 \%$ in cycle 1 , and this was maintained in subsequent cycles. Overall, the cumulative percentage of patients with a sustained CR over 4 cycles was $53 \%$. Notably, this study showed that NEPA plays an important role in managing CINV also in a later phase (6 to 21 days from chemotherapy). Indeed, in each cycle patients that reached CR experienced a significantly better control of very late nausea and/or vomiting than those who experienced no CR. ${ }^{36}$ Moreover, another study explored the timing flexibility of NEPA administration by analyzing the occupancy of the $\mathrm{NK}_{1}$ receptor in the brain via positron emission tomography and NEPA plasma concentration by pharmacological models. The results suggested the possibility to administer NEPA closer to initiation of chemotherapy than the recommended $60 \mathrm{~min}^{37}$

Lastly, a very recent cost-effectiveness analysis conducted to compare NEPA versus an aprepitant plus granisetron regimens in patients receiving HEC suggests that NEPA, by achieving a superior CINV prevention, is highly cost-saving due mainly to lower medical costs of CINVrelated events. $^{38}$

\section{Conclusion}

In this article, we reviewed the pharmacological characteristics of the classes of the $5 \mathrm{HT}_{3}$-RAs and the $\mathrm{NK}_{1}$-RAs and the most relevant CINV risk factors, both therapy- and patient-related and we defined the role of NEPA, which is a single oral dose combining a $\mathrm{NK}_{1}$-RA and a $5 \mathrm{HT}_{3}$-RA. NEPA ensures the coverage of the 5 days post-treatment, without any additional $5 \mathrm{HT}_{3}-\mathrm{RA}$ or $\mathrm{NK}_{1}-\mathrm{RA}$ drug to be taken by patients at home for antiemetic prophylaxis. $3,22,32$ NEPA has also demonstrated to be effective and safe in both HEC and MEC. Finally, it drastically simplifies the therapy by reducing the number of single drug administrations needed, guaranteeing fully adherence to antiemetic guidelines, and consequently improving the control of CINV starting from the first cycle of chemotherapy, not interfering with the adherence to the chemotherapy treatment. Therefore, for its pharmacological and clinical features NEPA represents a major step forward in CINV prevention. 


\section{Disclosure}

$\mathrm{PC}$ is an employee of Italfarmaco SpA. The other authors report no possible conflicts of interest for this work.

\section{References}

1. Middleton J, Lennan E. Effectively managing chemotherapy-induced nausea and vomiting. Br J Nurs. 2011;20(17):S7-S8. doi:10.12968/ bjon.2011.20.Sup10.S7

2. Trigg ME, Higa GM. Chemotherapy-induced nausea and vomiting: antiemetic trials that impacted clinical practice. J Oncol Pharm Pract. 2010;16:233-244. doi:10.1177/1078155209354655

3. Warr D. Prognostic factors for chemotherapy induced nausea and vomiting. Eur J Pharmacol. 2014;722:192-196. doi:10.1016/j. ejphar.2013.10.015

4. Martin M. The severity and pattern of emesis following different cytotoxic agents. Oncology. 1996;53 Suppl 1:26-31. doi:10.1159/ 000227637

5. Navari RM, Aapro M. Antiemetic prophylaxis for chemotherapy-induced nausea and vomiting. $N$ Engl $J$ Med. 2016;374(14):1356-1367. doi:10.1056/NEJMra1515442

6. Hesketh PJ, Kris MG, Basch E, et al. Antiemetics: American society of clinical oncology clinical practice guideline update. J Clin Oncol. 2017;35:3240-3261. doi:10.1200/JCO.2017.74.4789

7. Roila F, Molassiotis A, Herrstedt J, et al. 2016 MASCC and ESMO guideline update for the prevention of chemotherapy- and radiotherapy-induced nausea and vomiting and of nausea and vomiting in advanced cancer patients. Ann Oncol. 2016;27:v119-v133. doi:10.1093/annonc/mdw270

8. NCCN Clinical Practice Guidelines in Oncology (NCCN Guidelines ${ }^{\circledR}$ ) Antiemesis Version 1. February 28, 2019

9. Rojas C, Thomas AG, Alt J, et al. Palonosetron triggers 5-HT(3) receptor internalization and causes prolonged inhibition of receptor function. Eur J Pharmacol. 2010;626(2-3):193-199. doi:10.1016/j.ejphar.2009.10.002

10. Gralla R, Lichinitser M, Van Der Vegt S, et al. Palonosetron improves prevention of chemotherapy-induced nausea and vomiting following moderately emetogenic chemotherapy: results of a double-blind randomized phase III trial comparing single doses of palonosetron with ondansetron. Ann Oncol. 2003;14(10):1570-1577. doi:10.1093/annonc/mdg417

11. Eisenberg P, Figueroa-Vadillo J, Zamora R, et al. Improved prevention of moderately emetogenic chemotherapy-induced nausea and vomiting with palonosetron, a pharmacologically novel 5-HT3 receptor antagonist: results of a Phase III, single-dose trial versus dolasetron. Cancer. 2003;98(11):2473-2482. doi:10.1002/cncr.11817

12. Saito M, Aogi K, Sekine I, et al. Palonosetron plus dexamethasone versus granisetron plus dexamethasone for prevention of nausea and vomiting during chemotherapy: a double-blind, double-dummy, randomised, comparative phase III trial. Lancet Oncol. 2009;10 (2):115-124. doi:10.1016/S1470-2045(08)70313-9

13. Lorusso V. Management of chemotherapy-induced nausea and vomiting by risk profile: role of netupitant/palonosetron. Ther Clin Risk Manag. 2016;12:917-925. doi:10.2147/TCRM.S89215

14. Lorusso V, Karthaus M, Aapro M. Review of oral fixed-dose combination netupitant and palonosetron (NEPA) for the treatment of chemotherapy-induced nausea and vomiting. Future Oncol. 2015;11 (4):565-577. doi:10.2217/fon. 14.260

15. Rapoport BL, Chasen MR, Gridelli C, et al. Safety and efficacy of rolapitant for prevention of chemotherapy-induced nausea and vomiting after administration of cisplatin-based highly emetogenic chemotherapy in patients with cancer: two randomised, active-controlled, double-blind, Phase 3 trials. Lancet Oncol. 2015;16(9):1079-1089. doi:10.1016/S1470-2045(15)00035-2

16. Aapro M, Carides A, Rapoport BL, Schmoll HJ, Zhang L, Warr D. Aprepitant and fosaprepitant: a 10-year review of efficacy and safety. Oncologist. 2015;20(4):450-458. doi:10.1634/theoncologist.2014-0229
17. Syed YY. Rolapitant: first global approval. Drugs. 2015;75:1941-1945. doi:10.1007/s40265-015-0485-8

18. Rapoport BL, Aapro M, Chasen MR, et al. Recent developments in the clinical pharmacology of rolapitant: subanalyses in specific populations. Drug Des Devel Ther. 2017;11:2621-2629. doi:10.2147/DDDT.S133943

19. Rojas C, Raje M, Tsukamoto T, Slusher BS. Molecular mechanisms of 5-HT(3) and NK(1) receptor antagonists in prevention of emesis. Eur J Pharmacol. 2014;722:26-37. doi:10.1016/j.ejphar.2013.08.049

20. Thomas AG, Stathis M, Rojas C, Slusher BS. Netupitant and palonosetron trigger NK1 receptor internalization in NG108-15 cells. Exp Brain Res. 2014;232(8):2637-2644. doi:10.1007/s00221-014-4017-7

21. Aapro M, Zhang L, Yennu S, et al. Preventing chemotherapy-induced nausea and vomiting with netupitant/ palonosetron,the first fixed combination antiemetic: current and future perspective. Future Oncol. 2019;15(10):1067-1084. doi:10.2217/fon-2018-0872

22. Dranitsaris G, Mazzarello S, Smith S, Vandermeer L, Bouganim N, Clemons M. Measuring the impact of guideline-based antiemetic therapy on nausea and vomiting control in breast cancer patients with multiple risk factors. Support Care Cancer. 2016;24 (4):1563-1569. doi:10.1007/s00520-015-2944-x

23. Dranitsaris G, Molassiotis A, Clemons M, et al. The development of a prediction tool to identify cancer patients at high risk for chemotherapy-induced nausea and vomiting. Ann Oncol. 2017;28 (6):1260-1267. doi:10.1093/annonc/mdx 100

24. Aapro M, Molassiotis A, Dicato M, et al.; PEER Investigators. The effect of guideline-consistent antiemetic therapy on chemotherapy-induced nausea and vomiting (CINV): the Pan European Emesis Registry (PEER). Ann Oncol. 2012;23(8):1986-1992. doi:10.1093/annonc/mds021.

25. Clark-Snow R, Affronti ML, Rittenberg CN, Nausea C-I. Vomiting (CINV) and adherence to antiemetic guidelines: results of a survey of oncology nurses. Support Care Cancer. 2018;26(2):557-564. doi:10.1007/s00520-017-3866-6

26. Aapro M, Rugo H, Rossi G, et al. A randomized phase III study evaluating the efficacy and safety of NEPA, a fixed-dose combination of netupitant and palonosetron, for prevention of chemotherapy-induced nausea and vomiting following moderately emetogenic chemotherapy. Ann Oncol. 2014;25(7):1328-1333. doi:10.1093/annonc/mdu101

27. Bošnjak SM, Stamatovic L, Borroni ME, et al. Efficacy and safety of oral NEPA (Netupitant/Palonosetron), the first fixed-combination antiemetic, in patients with gynecological cancers receiving platinum-based chemotherapy. Int $J$ Gynecol Cancer. 2018;28 (6):1153-1161. doi:10.1097/IGC.0000000000001292

28. Kimmick G, Dent S, Klem I. Risk of cardiomyopathy in breast cancer: how can we attenuate the risk of heart failure from anthracyclines and anti-HER2 therapies? Curr Treat Options Cardiovasc Med. 2019;21(6):30. doi:10.1007/s11936-019-0736-1

29. Spinelli T, Moresino C, Baumann S, Timmer W, Schultz A. Effects of combined netupitant and palonosetron (NEPA), a cancer supportive care antiemetic, on the ECG of healthy subjects: an ICH E14 thorough QT trial. Springerplus. 2014;3:389. doi:10.1186/2193-1801-3-389

30. Jordan K, Blättermann L, Hinke A, et al. Is the addition of a neurokinin-1 receptor antagonist beneficial in moderately emetogenic chemotherapy?-A systematic review and meta-analysis. Support Care Cancer. 2018;26(1):21-32. doi:10.1007/s00520-017-3857-7

31. De Laurentiis M, Bonfadini C, Lorusso V, et al. Incidence of nausea and vomiting in breast cancer patients treated with anthracycline plus cyclophosphamide-based chemotherapy regimens in Italy: NAVY observational study. Support Care Cancer. 2018;26(12):4021-4029. doi:10.1007/s00520-018-4259-1

32. Jordan K, Jahn F, Aapro M. Recent developments in the prevention of chemotherapy-induced nausea and vomiting (CINV): a comprehensive review. Ann Oncol. 2015;26(6):1081-1090. doi:10.1093/annonc/mdv138

33. Hesketh PJ, Rossi G, Rizzi G, et al. Efficacy and safety of NEPA, an oral combination of netupitant and palonosetron, for prevention of chemotherapy-induced nausea and vomiting following highly emetogenic chemotherapy: a randomized dose-ranging pivotal study. Ann Oncol. 2014;25(7):1340-1346. doi:10.1093/annonc/mdu110 
34. Zhang L, Lu S, Feng J, et al. A randomized phase III study evaluating the efficacy of single-dose NEPA, a fixed antiemetic combination of netupitant and palonosetron, versus an aprepitant regimen for prevention of chemotherapy-induced nausea and vomiting (CINV) in patients receiving highly emetogenic chemotherapy (HEC). Ann Oncol. 2018;29(2):452-458. doi:10.1093/annonc/mdx698

35. Schwartzberg L, Karthaus M, Rossi G, et al. Fixed combination of oral NEPA (netupitant-palonosetron) for the prevention of acute and delayed chemotherapy-induced nausea and vomiting in patients receiving multiple cycles of chemotherapy: efficacy data from 2 randomized, double-blind phase III studies. Cancer Med. 2019;8 (5):2064-2073. doi:10.1002/cam4.2091

36. Caputo R, Cazzaniga ME, Sbrana A, et al. Netupitant/palonosetron (NEPA) and dexamethasone for prevention of emesis in breast cancer patients receiving adjuvant anthracycline plus cyclophosphamide: a multi-cycle, Phase II study. BMC Cancer. 2020;20(1):232. doi:10.1186/s12885-020-6707-9

37. Baron-Hay S, Aapro M, Bernareggi A, et al. Timing flexibility of oral NEPA, netupitant-palonosetron combination, administration for the prevention of chemotherapy-induced nausea and vomiting (CINV). Support Care Cancer. 2019;27(4):1309-1317. doi:10.1007/s00520019-4640-8

38. Botteman M, Nickel K, Corman S, et al. Cost-effectiveness of a fixed combination of netupitant and palonosetron (NEPA) relative to aprepitant plus granisetron (APR + GRAN) for prophylaxis of chemotherapy-induced nausea and vomiting (CINV): a trial-based analysis. Support Care Cancer. 2020;28(2):857-866. doi:10.1007/ s00520-019-04824-y

39. Poli-Bigelli S, Rodrigues-Pereira J, Carides AD, et al. Addition of the neurokinin 1 receptor antagonist aprepitant to standard antiemetic therapy improves control of chemotherapy-induced nausea and vomiting. Results from a randomized, double-blind, placebo-controlled trial in Latin America. Cancer. 2003;97(12):3090-3098. doi:10.1002/ cncr. 11433
40. Hesketh PJ, Grunberg SM, Gralla RJ, et al. The oral neurokinin-1 antagonist aprepitant for the prevention of chemotherapy-induced nausea and vomiting: a multinational, randomized, double-blind, placebo-controlled trial in patients receiving high-dose cisplatin the Aprepitant Protocol 052 Study Group. J Clin Oncol. 2003;21 (22):4112-4119. doi:10.1200/JCO.2003.01.095

41. Grunberg S, Chua D, Maru A, et al. Single-dose fosaprepitant for the prevention of chemotherapy-induced nausea and vomiting associated with cisplatin therapy: randomized, double-blind study protocolEASE. $J$ Clin Oncol. 2011;29(11):1495-1501. doi:10.1200/ JCO.2010.31.7859

42. Warr DG, Hesketh PJ, Gralla RJ, et al. Efficacy and tolerability of aprepitant for the prevention of chemotherapy-induced nausea and vomiting in patients with breast cancer after moderately emetogenic chemotherapy. J Clin Oncol. 2005;23(12):2822-2830. doi:10.1200/ JCO.2005.09.050

43. Schwartzberg LS, Modiano MR, Rapoport BL, et al. Safety and efficacy of rolapitant for prevention of chemotherapy-induced nausea and vomiting after administration of moderately emetogenic chemotherapy or anthracycline and cyclophosphamide regimens in patients with cancer: a randomised, active-controlled, double-blind, phase 3 trial. Lancet Oncol. 2015;16(9):1071-1078. doi:10.1016/S1470-2045(15)00034-0

44. Di Maio M, Baratelli C, Bironzo P, et al. Efficacy of neurokinin-1 Receptor Antagonists in the Prevention of Chemotherapy-Induced Nausea and Vomiting in Patients Receiving Carboplatin-Based Chemotherapy: A Systematic Review and Meta-Analysis. Crit Rev Oncol Hematol. 2018;124:21-28. doi:10.1016/j.critrevonc. 2018.02.001

45. Jordan K, Gralla R, Rizzi G, et al. Efficacy Benefit of an NK1 Receptor Antagonist (NK1RA) in Patients Receiving Carboplatin: Supportive Evidence With NEPA (A Fixed Combination of the NK1 RA, Netupitant, and Palonosetron) and Aprepitant Regimens. Support Care Cancer. 2016;24(11):4617-25. doi:10.1007/s00520-0163304-1
Core Evidence

\section{Publish your work in this journal}

Core Evidence is an international, peer-reviewed open-access journal evaluating the evidence underlying the potential place in therapy of drugs throughout their development lifecycle from preclinical to post launch. The focus of each review is to evaluate the case for a new drug or class in outcome terms in specific indications and patient groups.

Submit your manuscript here: https://www.dovepress.com/core-evidence-journal
The manuscript management system is completely online and includes a very quick and fair peer-review system, which is all easy to use. Visit http://www.dovepress.com/testimonials.php to read real quotes from published authors. 